\title{
Multimedia Transfer using Wireless LAN: A Case Study
}

\author{
Prathamesh P. Churi \\ Department of Computer Engineering \\ SVKM's NMIMS Mukesh Patel School of \\ Technology Management and Engineering \\ Mumbai, India
}

\author{
Sanjay Deshmukh \\ Department of Computer Engineering \\ SVKM's NMIMS Mukesh Patel School of \\ Technology Management and Engineering \\ Mumbai, India
}

\begin{abstract}
Communication plays a paramount role in human life. Wireless LAN is more important because they can satisfy the requirements like mobility, relocation of the user and ad-hoc networking. Our paper "Multimedia Transfer using Wireless LAN" is concerned with establishing audio and video calls over Wireless LAN, We are using client-server model for this purpose, and a wireless router is used to create wireless LAN. Building wireless LAN is easier, cost effective and less time consuming than establishing wired LAN.
\end{abstract}

\section{Keywords}

WLAN, TCP.IP, RTP, Swings.

\section{INTRODUCTION}

Voice over IP (VoIP) has presented a unique opportunity for enterprises. Merging of data networks and voice networks over a common IP infrastructure can offer a dramatic reduction in the capital and operational expense of maintaining the separate voice and data infrastructure. Voice and data applications can enhance communications in a manner that reduces the need for face-to-face meetings. The transition from VoIP to Wireless Space is inevitable extension of trend and voice, and video over WLAN extends the reach of company's IP telephony and multimedia communication systems and

WLANs offers an easy and cost-effective alternative to the existing model of the communication system. It is very easy to setup WLAN in offices as it doesn't require laying of cables to single PC. WLAN is also a growing part of the enterprise communications landscape.

Developing real-time communication like voice and video over WLAN is a technically challenging task. The user of mobile device expects at least same functionalities to overcome the problems of traditional voice communication. Here we are establishing the WLAN communication with the help of wireless. However, the wireless networks are designed for the wireless transmission of data. An important factor for establishing WLAN is mobility and in addition to other factors were comes into the picture like time for transmission of data, the cost for establishing WLAN, etc.

WLAN made an alarming increase in the communication networks in addition to it provides the best-in-class voice and video quality, robust security embedded in the corporate security model, supports for both on-site and off-site mobility, high availability, and low total cost ownership.

\section{RELATED WORK}

Currently, there are technologies existing for transmitting voice over a long distance which is quite expensive. The systems like GTALK, SKYPE which are useful for low-cost communication. These low-cost technologies have some limitations like Skype has a maximum number of contacts should be fifty if you want to have more than fifty contacts on the same account you have to pay a tariff to Skype. Using the services of SKYPE and GTALK we need an internet connection.

WLAN provide a greater advantage of mobility and cost effective establishment of the communication system. It does not require an internet connection, and the hardware requirement for WLAN is also less as compared to Wired LAN.

There is some literature cited in past three year's paper. There is ample amount work done in wireless network medium.

Table I Literature Cited

\begin{tabular}{|c|c|c|c|}
\hline $\begin{array}{l}\text { Sr. } \\
\text { no }\end{array}$ & $\begin{array}{c}\text { Title and } \\
\text { Description }\end{array}$ & Year & Inferences \\
\hline 1 & $\begin{array}{l}\text { A Dynamic Rate } \\
\text { Selection Algorithm } \\
\text { for IEEE 802.11 } \\
\text { Industrial Wireless } \\
\text { LAN [5] } \\
\text { The multi-rate } \\
\text { support feature has } \\
\text { been introduced by } \\
\text { the IEEE } 802.11 \\
\text { standard to improve } \\
\text { the system } \\
\text { performance and } \\
\text { has been widely } \\
\text { exploited using rate } \\
\text { adaptation (RA) } \\
\text { strategies within } \\
\text { general purpose } \\
\text { wireless LANs. }\end{array}$ & 2017 & $\begin{array}{l}\text { - Plans revealed } \\
\text { ineffective for } \\
\text { modern real-time } \\
\text { communications, } \\
\text { and alternative } \\
\text { solutions, better } \\
\text { tailored for such a } \\
\text { particular field of } \\
\text { application, were } \\
\text { investigated. } \\
\text { The paper presents } \\
\text { a thorough } \\
\text { performance } \\
\text { analysis, carried } \\
\text { out to study the } \\
\text { behavior of the } \\
\text { addressed RA } \\
\text { schemes. }\end{array}$ \\
\hline 2 & $\begin{array}{l}\text { Experimental } \\
\text { Analysis of Various } \\
\text { Protocols on VoIP } \\
\text { Traffic } \\
\text { Different CODECs } \\
\text { in Wireless LAN [6] } \\
\text { This paper shows } \\
\text { the analysis of } \\
\text { different routing } \\
\text { protocols on VoIP } \\
\text { traffic with the } \\
\text { various codecs in } \\
\text { Wireless LAN. }\end{array}$ & 2016 & 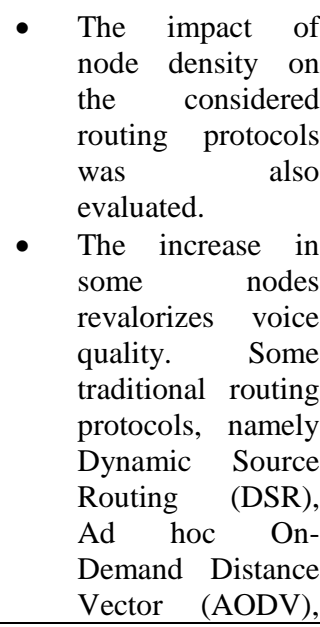 \\
\hline
\end{tabular}




\begin{tabular}{|c|c|c|c|}
\hline & & & $\begin{array}{l}\text { Dynamic MANET } \\
\text { On-Demand } \\
\text { (DYMO) and } \\
\text { Optimized Link } \\
\text { State Routing } \\
\text { (OLSR) have been } \\
\text { used. } \\
\text { Different QoS } \\
\text { parameters like } \\
\text { voice MOS, the } \\
\text { end to end delay, } \\
\text { voice jitter, } \\
\text { throughput and } \\
\text { packet delivery } \\
\text { ratio are taken to } \\
\text { evaluate the } \\
\text { performance. }\end{array}$ \\
\hline 3 & $\begin{array}{l}\text { Using MAC Frame } \\
\text { Header for Efficient } \\
\text { Multimedia } \\
\text { Streaming over } \\
\text { IEEE } 802.11 \\
\text { Wireless LAN [7] } \\
\text { The idea of tradeoff } \\
\text { between video } \\
\text { quality and } \\
\text { throughput has been } \\
\text { proposed in this } \\
\text { paper; implemented } \\
\text { through a } \\
+ \text { modification to } \\
\text { IEEE } 802.11 \text { frame } \\
\text { format such that } \\
\text { some areas are } \\
\text { marked to designate } \\
\text { a frame as a video } \\
\text { frame. }\end{array}$ & 2015 & $\begin{array}{l}\text { - Selected frames } \\
\text { are proposed to be } \\
\text { treated differently } \\
\text { from regular data } \\
\text { frames to enhance } \\
\text { video throughput } \\
\text { and reduce } \\
\text { transmission time } \\
\text { delay. } \\
\text { Results achieved } \\
\text { are } \\
\text { promising; quite } \\
\text { although video } \\
\text { frames with high } \\
\text { motion contents } \\
\text { possess degraded } \\
\text { signal quality, } \\
\text { perceptually the } \\
\text { results seem } \\
\text { satisfactory. }\end{array}$ \\
\hline 4 & $\begin{array}{l}\text { QoS-Guaranteed } \\
\text { Realtime } \\
\text { Multimedia Service } \\
\text { Provisioning on } \\
\text { Broadband } \\
\text { Convergence } \\
\text { Network (BCN) } \\
\text { with IEEE 802.11e } \\
\text { Wireless LAN and } \\
\text { Fast/Gigabit } \\
\text { Ethernet [8] } \\
\text { QoS Support } \\
\text { Polling Scheme for } \\
\text { Multimedia Traffic } \\
\text { in Wireless LAN } \\
\text { MAC Protocol [10] }\end{array}$ & $\begin{array}{l}2007 \\
2008\end{array}$ & $\begin{array}{l}\text { - In this paper, } \\
\text { authors proposed a } \\
\text { session and } \\
\text { connection } \\
\text { management } \\
\text { architecture for the } \\
\text { QoS-guaranteed } \\
\text { real-time } \\
\text { multimedia service } \\
\text { provisioning on } \\
\text { BCN, with Q- } \\
\text { SIP/SDP, resource } \\
\text { reservation } \\
\text { protocol with } \\
\text { traffic engineering } \\
\text { extension, and } \\
\text { CAC functions. } \\
\text { The detailed } \\
\text { interaction and } \\
\text { scenario and } \\
\text { related algorithms } \\
\text { for a QoS- } \\
\text { guaranteed real- } \\
\text { time multimedia } \\
\text { session, resource }\end{array}$ \\
\hline
\end{tabular}

\begin{tabular}{|c|c|c|c|}
\hline & $\begin{array}{l}\text { wireless local area } \\
\text { networks (LANs) } \\
\text { but is limited in } \\
\text { 802.11-based } \\
\text { wireless LANs. A } \\
\text { polling-based } \\
\text { scheme called the } \\
\text { point coordination } \\
\text { function (PCF) was } \\
\text { developed for } \\
802.11 \text { LANs to } \\
\text { support the } \\
\text { transmission of } \\
\text { multimedia traffic. }\end{array}$ & & user \\
\hline 5 & $\begin{array}{l}\text { Performance } \\
\text { Evaluation } \\
\text { Multimedia } \\
\text { Services Over } \\
\text { Wireless LAN Using } \\
\text { Routing Protocol } \\
\text { Optimized Link } \\
\text { State Routing } \\
\text { (OLSR) [9] } \\
\text { Factors that affect } \\
\text { the streaming is } \\
\text { bandwidth. These } \\
\text { factors may cause } \\
\text { the process stream } \\
\text { is often disrupted } \\
\text { when there is not } \\
\text { enough bandwidth, } \\
\text { so that resulted in } \\
\text { the loss and delay in } \\
\text { delivery. To reduce } \\
\text { the occurrence of } \\
\text { loss and delay, a } \\
\text { routing protocol is } \\
\text { needed that can } \\
\text { support multimedia } \\
\text { service quality } \\
\text { package that will be } \\
\text { passed on wireless } \\
\text { LAN networks }\end{array}$ & 2012 & $\begin{array}{l}\text { - In this paper will } \\
\text { be evaluated on } \\
\text { the WLAN } \\
\text { performance } \\
\text { multimedia } \\
\text { services with the } \\
\text { help of routing } \\
\text { protocol r Link } \\
\text { Optimized r Routing } \\
\text { State re } \\
\text { (OLSR). }\end{array}$ \\
\hline 6 & $\begin{array}{l}\text { Polling Strategy for } \\
\text { Wireless } \\
\text { Multimedia LANs } \\
\text { [11] } \\
\text { Wireless local area } \\
\text { networks (WLANs) } \\
\text { are a viable } \\
\text { technology for } \\
\text { multimedia traffic. } \\
\text { One of the most } \\
\text { common WLANs } \\
\text { standards being } \\
\text { adopted as a mature } \\
\text { technology is the } \\
\text { IEEE 802.11 } \\
\text { standard. This paper }\end{array}$ & 2006 & $\begin{array}{l}\text { - A mathematical } \\
\text { model based on } \\
\text { embedded Markov } \\
\text { chain theory and } \\
\text { the generation } \\
\text { function was used } \\
\text { to predict the mean } \\
\text { queue length and } \\
\text { data packet } \\
\text { waiting time. } \\
\text { Mathematical } \\
\text { analysis and } \\
\text { simulations } \\
\text { validated the } \\
\text { efficiency of the } \\
\text { new strategy. } \\
\text { The results show } \\
\text { that parallel }\end{array}$ \\
\hline
\end{tabular}




\begin{tabular}{|c|c|c|c|}
\hline & $\begin{array}{l}\text { presents a new } \\
\text { polling strategy for } \\
\text { wireless multimedia } \\
\text { LANs with variable } \\
\text { packet lengths, } \\
\text { which synchronizes } \\
\text { polling and } \\
\text { transmission of the } \\
\text { information } \\
\text { packets. }\end{array}$ & & $\begin{array}{l}\text { system's mean } \\
\text { queue length, } \\
\text { information packet } \\
\text { waiting time, and } \\
\text { polling cycle time } \\
\text { are all less than for } \\
\text { the non-parallel } \\
\text { system and that the } \\
\text { improved system } \\
\text { is more stable and } \\
\text { has greater } \\
\text { capacity }\end{array}$ \\
\hline 7 & $\begin{array}{l}\text { Improving Wireless } \\
\text { LAN Performance } \\
\text { in the Presence of } \\
\text { Integrated } \\
\text { Multimedia } \\
\text { Services [12] } \\
\text { A new multiplexing } \\
\text { scheme for } \\
\text { multimedia over } \\
\text { wireless networks is } \\
\text { proposed. The } \\
\text { proposed system } \\
\text { greatly accelerates } \\
\text { data services in the } \\
\text { presence of } \\
\text { multimedia services } \\
\text { compared to other } \\
\text { projects. }\end{array}$ & 2009 & $\begin{array}{l}\text { - Our scheme is also } \\
\text { more energy- } \\
\text { aware than other } \\
\text { schedulers The } \\
\text { system provides } \\
\text { soft QoS guarantee } \\
\text { by enforcing } \\
\text { cooperative coding } \\
\text { in multimedia } \\
\text { stations. } \\
\text { The system results } \\
\text { in lower rates of } \\
\text { call rejection or } \\
\text { dropping due to } \\
\text { handover. It is } \\
\text { suited for } \\
\text { implementation at } \\
\text { the base station in } \\
\text { an infrastructure } \\
\text { basic service sets. }\end{array}$ \\
\hline
\end{tabular}

\section{ANALYSIS OF PROBLEM}

Wireless LAN have a significant niche in the LAN market quickly. As adjusts to traditional wired LAN, they satisfy mobility, relocation and ad-hoc networking requirements and provides a way to cover locations that are difficult to wire. Communication is a prime primitive since, from ancient time, various methods have been deployed communication.

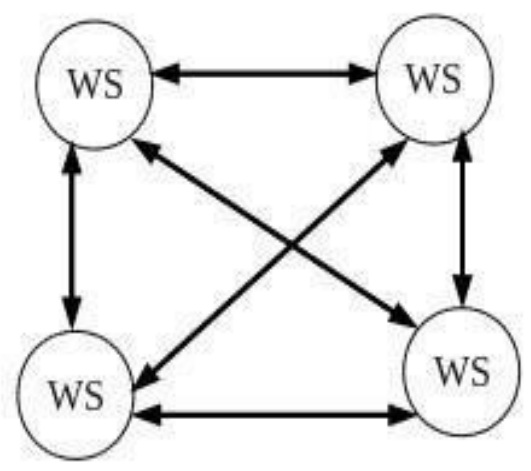

Fig. 1 Ad-hoc networking

The Private Branch Exchange office owned by service providers. These were wired network a copper line is connected subscriber home to local office. Switching is done by the hardware like processor, and switching offices need to be setup, and hierarchical network backbone need to be established to route calls.

\section{LAYERING MODEL OF TCP/IP}

\subsection{TCP/IP Protocol Stack [2]}

$\mathrm{TCP} / \mathrm{IP}$ is the protocol suites upon which all Internet communication is based. Rules sometimes referred to as protocol stack because it indicates a layered approach used to design the networking software.

Table II TCP/IP Layering Structure

\begin{tabular}{|c|l|l|}
\hline Layer & \multicolumn{1}{|c|}{ Name of Layer } & \multicolumn{1}{c|}{ Purpose of Layer } \\
\hline Layer 1 & Application & $\begin{array}{l}\text { Specifies how a particular } \\
\text { application uses a network }\end{array}$ \\
\hline Layer 2 & Transport & $\begin{array}{l}\text { Specifies how to ensure } \\
\text { reliable transport of data }\end{array}$ \\
\hline Layer 3 & Internet & $\begin{array}{l}\text { Specifies Packet format and } \\
\text { Routing }\end{array}$ \\
\hline Layer 4 & Data link & $\begin{array}{l}\text { Specifies Frame organization } \\
\text { and transmission }\end{array}$ \\
\hline Layer 5 & Physical & $\begin{array}{l}\text { Specifies the underlying } \\
\text { network hardware }\end{array}$ \\
\hline
\end{tabular}

\subsection{Session Initialization Protocol (SIP)}

Session Initialization Protocol is a signaling protocol, widely used for controlling the multimedia. This protocol used for creating, modifying and terminating two-party(unicast) or multiparty(multicast) sessions consisting of one or several media. The possible applications example consisting of voice and video stream communications.

\subsection{Real-time Transport Protocol (RTP)}

Streaming media has certain characteristics as against the traditional media, and it warrants the separate transport protocol. Streaming media of following types.

a) Real-time delivery of media as in the case of the media -on -demand application. In this case, a server may stream a stored media from a file while the client receives and playback the media in real time

b) Delivery of real-time data. A typical example is a video conferencing application wherein the captured audio and video are being streamed in real-time.

\section{DESIGNING AND WORKING}

Voice and video over WLAN are entirely designed by clientserver model and router is used for establishing this system and client-server model as shown in Fig.2.

The server acts as a virtual machine in the system when the communication between clients stars. The server just establishes the Session between clients, and it sits quite until client machines stop their conversation. In designing this system, we used Java as a programming language. The Front end was designed using Java Swings and Oracle [4] as a Database to store clients' registration information, and Multithreading is acted as the key role in audio and video communication. Features like text, messaging and file sharing are also embedded into this system. Microsoft Access is used as client side database. 


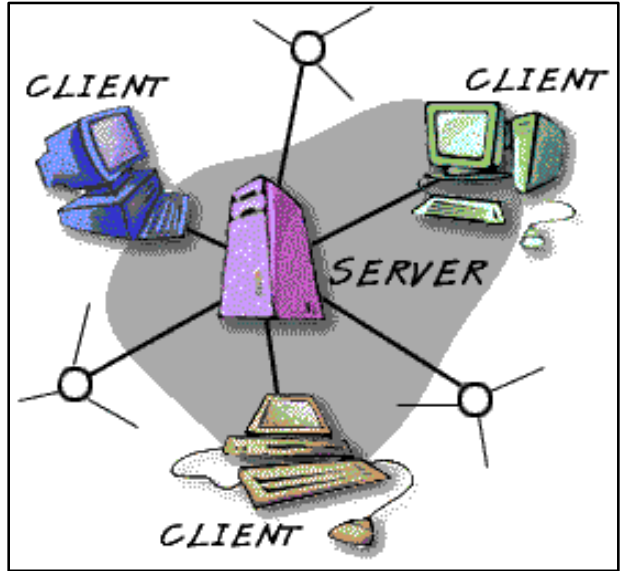

Fig.2 Client Server Model

The user or client first registers on the server with various types of parameters like username, password, email-id, etc. After login on the availability of another client, he/she can send online as well as offline messages. Chat history is stored on the server side as well as client side. In file sharing client can send any type files including documents, images, audio, and video, etc. In audio and video calling the first client waits until another client accepts call request and after call receiving communication is done it may be audio or video. Hereafter the establishment of call server acts as the virtual machine.

\section{APPLICATIONS}

It will be useful for small scale industries for giving the instructions to employees by making audio and video calls without using internet bandwidth. It will be helpful for educational institute since it is very easy to establish an audio and video conference using the bandwidth of router by which departments can be connected faster and communicated. Small organizations which are looking for cost cutting and time-saving means of communication can use this system.

\section{CONCLUSION}

Currently, systems are available in the market for inexpensive communication. However, they have constraints like the need for internet connection. In this paper, we attempt to introduce cheaper audio and video communication with some additional features like text messaging and file sharing over WLAN. As it requires only a wireless router, personal computer and it doesn't require an internet connection, this system is very profitable. It is easy to setup the system as no additional wiring is required in case of the conventional system used for communication. This will be a great useful application in small-scale industries as well as educational institutions. It will be helpful as cost cutting means that facilitate audio and video communication.

\section{ACKNOWLEDGEMENT}

I (Prathamesh Churi) wants to thank my brother Mr. Rohan Chaudhari for his encouragement in research.

\section{REFERENCES}

[1] Ravindra L. Pardi, Vishwas T. Gaikwad. "Module wise Design of Voice and Video over Wireless LAN"International Journal of Computer Trends and Technology (IJCTT),V1(1):100-105 March to April Issue 2011. ISSN 2231-2803. www.ijcttjournal.org. Published by Seventh Sense Research Group.
[2] Regis J. Bates, Donald W. Gregory,Voice and Data communications, ISBN -9780072131888, McGraw Hill Professional, 2001

[3] Voice and Video over wireless LAN by Ravindra L. Pardhi et al. / International journal on computer science and Engineering(IJCSE)

[4] Behrouz A Forozan "TCP/IP Protocol suite" 3rd edition. [5] F. Tramarin, S. Vitturi and M. Luvisotto, "A Dynamic Rate Selection Algorithm for IEEE 802.11 Industrial Wireless LAN," in IEEE Transactions on Industrial Informatics, vol. 13, no. 2, pp. 846-855,

[6] S. T. Chandel and S. Sharma, "Experimental analysis of various protocols on VoIP traffic with different CODECs in Wireless LAN," 2016 Fifth International Conference on Eco-friendly Computing and Communication Systems (ICECCS), Bhopal, 2016, pp. 109-113.

[7] S. Shaheen, A. Khannum, S. A. Khan, U. Akram and M. Y. Javed, "Using MAC frame header for efficient multimedia streaming over IEEE 802.11 wireless LAN," 2015 International Conference on Computer, Communications, and Control Technology (I4CT), Kuching, 2015, pp. 570-574.

[8] Y. T. Kim, Y. C. Jung and S. W. Kim, "QoS-guaranteed realtime multimedia service provisioning on broadband convergence network $(\mathrm{BcN})$ with IEEE 802.11e wireless LAN and Fast/Gigabit Ethernet," in Journal of Communications and Networks, vol. 9, no. 4, pp. 511523, Dec. 2007.

[9] T. Setiadi, Y. Bandung and A. Z. R. Langi, "Performance evaluation of multimedia services over wireless LAN using routing protocol Optimized Link State Routing (OLSR)," 2012 International Conference on Cloud Computing and Social Networking (ICCCSN), Bandung, West Java, 2012, pp. 1-4.

[10] Z. Yang and D. Zhao, "QoS support polling scheme for multimedia traffic in wireless LAN MAC protocol," in Tsinghua Science and Technology, vol. 13, no. 6, pp. 754-758, Dec. 2008.

[11] Z. Yang and D. Zhao, "Polling strategy for wireless multimedia LANs," in Tsinghua Science and Technology, vol. 11, no. 5, pp. 606-610, Oct. 2006.

[12] S. A. Halawa and H. M. Elkamchouchi, "Improving wireless LAN performance in the presence of integrated multimedia services," 2009 National Radio Science Conference, New Cairo, 2009, pp. 1-9.

[13] K. Kathiravan, R. Ramya and T. S. Titus, "Multimedia Transmission over Wireless LANs," 2009 First International Conference on Computational Intelligence, Communication Systems and Networks, Indore, 2009, pp. 505-510.

[14] J. T. Park, J. W. Nah, S. Wang and S. M. Chun, "Context-Aware Mobility Management with Energy Efficiency for Multimedia Streaming Service in Wireless LAN," 2009 6th IEEE Consumer Communications and Networking Conference, Las Vegas, NV, 2009, pp. 1-6.

[15] T. Hiraguri, M. Ogawa, M. Umeuchi and T. Sakata, "Study of Power Saving Scheme Suitable for Wireless LAN in Multimedia Communication," 2009 IEEE Wireless Communications and Networking Conference, Budapest, 2009, pp. 1-6. 